\title{
THE IDENTIFICATION MODEL ON SWIMMING ATHLETES SKILL
}

\section{Fahrur Rozi, Hari Setijono, Nining Widyah Kusnanik}

\author{
Institution, city, country, State University of Surabaya
}

\begin{abstract}
Анотація. Це дослідження має на меті розробити інструментальний тест і антропометричні, біомоторні вимірювання та навички плавання за допомогою моделі порівняння та програмного забезпечення. Інструмент використовується для виявлення майстерності або здібностей спортсменів з плавання. Вид використовуваних досліджень $є$ кількісним, виходячи з моделі розробки. Зразок береться за допомогою методу квотного відбору проб, в якому беруть участь 60 осіб (30 чоловіків та 30 жінок) для першого тестування. Крім того, 120 осіб (60 чоловіків і 60 жінок) - для другого тестування, тому загальна кількість вибірки становить 180 осіб. Дані аналізуються за допомогою фракторного та дискримінантного аналізу за допомогою програмного забезпечення SPSS. У результаті в першому періоді маємо 16 пунктів інструментального тесту для чоловіків і жінок. Результатом за другий період є використання фракторного аналізу на суму 0,60 та отримано 16 інструментальних пунктів для чоловіків та 14 - для жінок. У результаті третього періоду з використанням фракторного та дискримінантного аналізів отримано 12 інструментальних тестів для чоловіків та 12 - для жінок. Використовувалося програмне забезпечення FASTI (ідентифрікація талантів плавання за Фахрурозі).

Ключові слова: ідентифікація, навички плавання, талант, плавання.
\end{abstract}

\section{Fahrur Rozi, Hari Setijono, Nining Widyah Kusnanik THE IDENTIFICATION MODEL ON SWIMMING ATHLETES' SKILL}

\begin{abstract}
This study aims to develop an instrumental test and anthropometric, biomotor measurements and swimming skills by a comparison model and software. The tool is used to identify the skills or abilities of athletes in swimming. The type of research used is quantitative, based on the development model. The sample is taken using a quota sampling method involving 60 persons (30 men and 30 women) for the first test. In addition, 120 persons (60 men and 60 women) are involved in the second testing, so the total sample size constitutes 180 subjects. Data are analyzed by factor and discriminant analysis using SPSS software. As a result, in the first period, we have 16 instrumental test points for men and women. The result of the second period was the use of factor analysis totaling to 0.60 and obtaining 16 tool points men and $14-$ for women. As a result of the third period, 12 instrumental tests for men and 12 for women were obtained using factor and discriminant analyzes. FASTI

(Fahrurozi Swimming Talent Identification) software was used.
\end{abstract}

Keywords: identification, swimming skills, talent, swimming

Introduction. The Indonesian government always tries to encourage and create system, model, and program designed to identify and develop the young generation who has talent on sport. The support given by the government is in purpose to develop young generation comprehensively, so therefore, can achieve good accomplishments (Cooke, et al., 2010). The successful athletes are the qualified individual in certain physical activity and following long term program planned along several years(Bompa \& Carrera, 2015). Moreover, the hard work, commitment and athletes exercising which is performed systematically and well programed will lead successfulness of athletes' successfulness as well.

The guidance in finding the talent is the first and basic factor in achieving sport achievement. A good athlete absolutely does not instantly being born with the excellence talent, yet it is found out through routine exercise and guidance. Thus, the screening process in early age will provide to repair the bad pattern in identifying the athletes (Parsonage, et al., 2014) a series of standard fitness tests was con- ducted. Overall the group's CSMTs competency ratings were low, but task dependent. The proportion of competent players ranged from $14 \%$ for a single leg squat to $70 \%$ for a double to single leg landing. Players were subsequently grouped based on their CSMTs ratings using cluster analysis. This analysis classified players on features of the CSMT battery that distin- guished between groups rather than an arbitrary score. Fitness test scores were then compared between the 3 groups iden-tified. The "gene- 


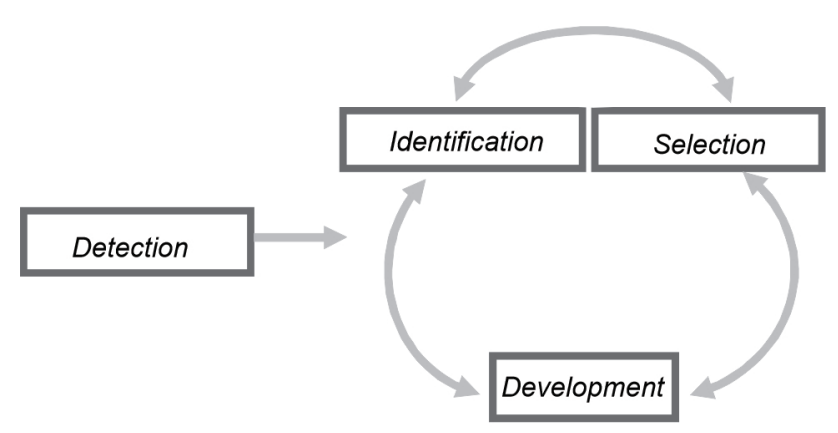

Figure 1 - The Key Steps in Identification and Development of Talent Process (Williams \& Frank, 1998 in Williams \& Reilly (2000)

ral low competency" group jumped $9.1 \mathrm{~cm}$ lower $(p=0.0218$. Anshel \& Lidor (2012) argue that programs which have purpose to predict the successfulness of sport in the future or called as talent detection or talent identification is planned to identify the young athletes which has excellent potential. Afterwards, Russell (1989) and Borms (1996) in Williams \& Reilly (2000) state that there are four steps to identify the talent of athletes (fig. 1):

1. Talent detection refer to the finding of potential athlete which not currently involving in sports.

2. Talent identification refers to the process in knowing the current participant with its potential to be elite athletes.

3. The talent development implies that athletes are provided with appropriate learning environment, so therefore the athletes has chance to realize their own potential.

4. Talent selection involves continuous process to identify the athletes in each of the steps.

According to Vrljic \& Mallett (2008), the talent detection refers to the individual quality matching for certain sports. In this step, the individual does not participate in the sports yet. Then, the identification talent step is trying to identify individuals' potential to be professional athletes. The talent identification is often following with the talent selection and refers to the continuous process in every steps which shows the level of performance to be included into team or group.

In another literature, the suggestion that can be proposed dealing with the factor of the athletes' successfulness in talent identification come from several field such as anthropometric, motoric, mental, physical quality and contextual (see figure 2). Further, it is recommended that every sport should develop identification program specifically (Van Den Bosch \& De Cocq, 2006; Elferink-Gemser, et al., 2005; Kondrič, 2009; Régnier, et al., 1993; Williams \& Reilly, 2000; Faber et al., 2012).
Generally, identification system in Indonesia in the current year mostly refers to the system that has been implemented in Australia. The aim of Australia's government in creating Sport Search program is to prepare for both national and international events. The test results are used to predict the athletes' potential in all of sports field. The benefit of Sport Search is the athletes can choose several sports based on their interest. Meanwhile, the lack is that it cannot predict specifically to the field the athletes really suitable on. Several sports have specification and characters, so that the test should be specific to one or two sports. In Indonesia, the swimming sports in Indonesia are currently does not have specific points of test to identify.

The talent identification in Indonesia has ever been implemented and developed by Deputy Assistant of Sports Training Minister of Sports Indonesia 2015 which including height $(\mathrm{cm})$, weight $(\mathrm{kg})$, arm length $(\mathrm{cm})$ and foot length $(\mathrm{cm})$ and physical mesurement such as sit and reach test, max swimming sprint (25 m flying start), acceleration swimming (15 m push start), vertical jump, test push up (30 seconds), test pull up (30 seconds), test sit up (30 seconds) and aerobic swim $\left(\mathrm{vo}_{2}\right.$ max) for 15 minutes.

The result test has never been published and no software that broadly published to the society. Thus, based on identification talent test on swimming by Asdep Pembibitan Olahraga Kemenpora Republik Indonesia 2015 (Deputy Assistant of Sports Training Minister of Sports Indonesia 2015), it should be improved so that the identfication model test will be obtained. The development is conducted through three dominant factors including antropomethric, biomotor, and swimming. It has function to produce antrophomethric, biomotoric and swimming test instrument with the equation model.

Method. This research is quantitative research with development model approach. The series of development model start from 1) test organization

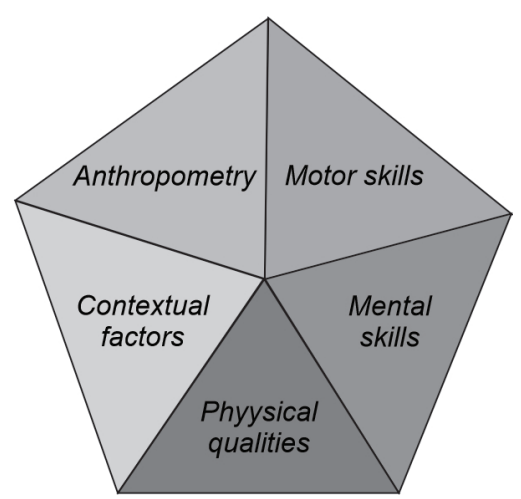

Figure 2 - Domain or Region to Identify Talent (Faber, et al., 2012) 
purpose, 2) the ability and talent identification, 3) literature review, 4) indicator and operational concept, 5) points organization, 6) experts' validation, 7) first testing, 8) second testing, 9) final format (Maksum, 2012).

Afterwards, this research is planned in three periods of time including:

1. Analysis of need, product development, expert validation, practical analysis, effectiveness to obtain anthropometric measurement design products instrument, bio motor test, swimming ability and identification swimming talent;

2. Testing the design products instrument of period 1 with the first sample and thus being analyzed with factor analysis.

3. Testing the design products instrument of period 2 with the second sample and thus being analyzed with factor analysis. The data results analyzed with factor analysis and discriminant analysis to obtain equation model and software as Last Test Instrument Product to identify swimming talent.

The research subjects are involving 180 peoples in 7-10 ages. The sample taken using quota sampling technique with the amounts are 60 people (30 men and 30 women) from Gresik Regency swimming group for first testing, and 120 people (60 men and 60 women) from Sidoarjo and Surabaya as for the second testing. The data is taken from anthropometric, biometric, and swimming ability. Afterwards, the data is analyzed using factor analysis and discriminant analysis using SPSS. The variable or instrument is including 18 items from anthropometric measurement: 1) body weight, 2) height, 3) arm span, 4) foot width, 5) palm width, 6) foot length,7) leg length which also including some bio motor test: 1) sit and reach, 2) pull up, 3) push up, 4) sit up, and 5) standing broad jump. Afterwards, swimming skills tests are 1) floating, 2) gliding, 3) 15 meters kick board, 4) 15 meters swimming, and 5) swimming 25 meters, 6) 15 minutes swimming.

Result. The research result of period 1 from 18 of research instru-ments is chosen 16 items as Instrument Design Product. The two of instruments which is eliminated is Push Up and 25 meters swimming.

The research result of period-2 with factor analysis measurement shows that there are two women instruments that being eliminated due to the lack of requirement of factor value $<$ $<0.60$ with gliding $=0.596$ and floating $=0.582$, meanwhile one of men instrument that is sit and reach $=0.572$ is maintained as expert suggestion.

The research result of period-3 based on factor analysis measurement shows that the two men instruments including standing broad jump $=0.052$ and gliding $0.522=$ are being eliminated. Whereas, sit and reach instrument $=0.581$ is maintained in accordance with experts' suggestion. Otherwise, there are no measurement results that being eliminated for women since all of the instruments are fulfilling the requirement of factor values $<0.60$. Afterwards, the measurement using discriminant analysis with p-value (sig) must meet the requirement $<0.05$ significant level. Thus, Ha is accepted and Ho is rejected. The measurement for men in floating instrument $=0.064$ and palm width $=0.092$ cannot be used. Meanwhile, sit and reach $=0.116$ still to be maintained based on experts' suggestion. The instrument for women in weight $=0.107$, and foot width $=0.072$ is not applied.

The result of period-3 measurement is chosen 12 instruments items as the last product. For men, the test are including weight, height, arm span, leg length, palm width, foot width, sit and reach, pull up, sit up, 15 meters kick board, 15 meters swimming, and 15 minutes swimming. For women, the test are including height, arm span leg length, palm width, foot length, sit and reach, pull up, sit up, standing broad jump, 15 meters kick boards, 15 meters swimming, and 15 minutes swimming.

The measurement result to determine the discriminant equation cam be seen in the Canonical Discriminant Function Coefficients as follows (Tabl. 1).

Table 1 above explain about coefficient of each instruments (variable) that can be shaped in discriminant function as equation formula as follows: Dmen $=-2.462+(0.124 \mathrm{BB})+(0.082 \mathrm{~TB})-$ $(0.109 \mathrm{RL})+(0.059 \mathrm{PT})-(0.744 \mathrm{LTT})+$ $+(0.124$ PTK $)-(0.026$ SAR $)+(0.005$ PUL $)+$

Table 1 - Canonical discriminant function coefficients

\begin{tabular}{|l|c|c|}
\hline \multirow{2}{*}{} & \multicolumn{2}{|c|}{ Function } \\
\cline { 2 - 3 } & 1 (men) & $\mathbf{1}$ (women) \\
\hline Weight (BB) & .124 & \\
\hline Height (TB) & .082 & .133 \\
\hline Arm Span (RL) & -.109 & -.161 \\
\hline Leg Length (PT) & .059 & .025 \\
\hline Palm Width (LTT) & -.744 & .068 \\
\hline Foot Length (PTK) & .124 & .292 \\
\hline Sit and Reach(SAR) & -.026 & -.001 \\
\hline Pull Up(PUL) & .005 & .028 \\
\hline Sit Up(SIT) & .039 & .067 \\
\hline Standing Broad Jump(SBJ) & & -.010 \\
\hline Kick Board 15 meters (K15) & -.037 & -.102 \\
\hline 15 meters Swimming (B15) & -.117 & -.015 \\
\hline 15 Minutes Swimming (R15) & .006 & .007 \\
\hline (Constant) & -2.462 & -7.100 \\
\hline
\end{tabular}


Table 2 - Men classification result

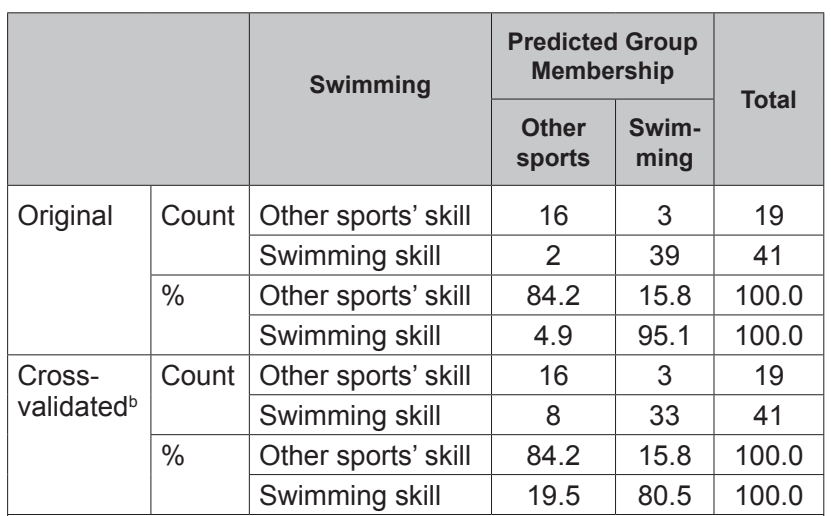

a. $91.7 \%$ of original grouped cases correctly classified.

b. Cross validation is done only for those cases in the analysis. In cross validation, each case is classified by the functions derived from all cases other than that case.

c. $81.7 \%$ of cross-validated grouped cases correctly classified.

Tabel 3 - Women Classification Result

\begin{tabular}{|c|c|c|c|c|c|}
\hline & & \multirow{2}{*}{ Swimming } & \multicolumn{2}{|c|}{$\begin{array}{l}\text { Predicted Group } \\
\text { Membership }\end{array}$} & \multirow[b]{2}{*}{ Total } \\
\hline & & & $\begin{array}{c}\text { Other } \\
\text { Sports } \\
\text { Swimming }\end{array}$ & $\begin{array}{l}\text { Swim- } \\
\text { ming }\end{array}$ & \\
\hline \multirow[t]{4}{*}{ Original } & \multirow[t]{2}{*}{ Count } & Other Sports & 20 & 3 & 23 \\
\hline & & Swimming & 0 & 37 & 37 \\
\hline & \multirow[t]{2}{*}{$\%$} & Other Sports & 87.0 & 13.0 & 100.0 \\
\hline & & Swimming & .0 & 100.0 & 100.0 \\
\hline \multirow{4}{*}{$\begin{array}{l}\text { Cross- } \\
\text { validated }^{\mathrm{b}}\end{array}$} & \multirow[t]{2}{*}{ Count } & Other Sports & 18 & 5 & 23 \\
\hline & & Swimming & 4 & 33 & 37 \\
\hline & \multirow[t]{2}{*}{$\%$} & Other Sports & 78.3 & 21.7 & 100.0 \\
\hline & & Swimming & 10.8 & 89.2 & 100.0 \\
\hline
\end{tabular}

a. $95.0 \%$ of original grouped cases correctly classified.

b. Cross validation is done only for those cases in the analysis. In cross validation, each case is classified by the functions derived from all cases other than that case.

c. $85.0 \%$ of cross-validated grouped cases correctly classified.

+0.039 SIT $)-(0.037$ K15 $)-(0.117$ B15 $)+$ $+(0.006$ R15); Dwomen $=-7.100+(0.133 \mathrm{~TB})-$ $(0.161 \mathrm{RL})+(0.025 \mathrm{PT})+(0.068 \mathrm{LTT})+$ $+(0.292$ PTK $)-(0.001$ SAR $)+(0.028$ PUL $)+$ $+(0.067 \mathrm{SIT})-(0.010 \mathrm{SBJ})-(0.102 \mathrm{~K} 15)-$ $(0.015 \mathrm{~B} 15)+(0.007 \mathrm{R} 15)$.

Then, based on the equation formula above, the most dominant variable value used to predict the difference of other sports and swimming for men is foot length (PTK) and weight (BB) with the coefficients value is 0.124 . Meanwhile, for women, the foot length (PTK) with coefficients value is 0.292 . Children around 7-10 years old are considered to have good skill in swimming if they can obtain value $>-0.98963$ for men and $>-0.64565$ for women, but if the value is $<-0.98963$ for men and $<-0.64565$ for women, hence it can be said that the children has talent in other sports rather than swimming.

The variable averages used to differ swimming talent categorization sometimes has the same proximity value, so therefore it can be obtained the amount of sample that include into swimming categorization and non-swimming categorization. The classification of categorization in swimming skill can be described in the Table 2 for men and Table 3 for women, as bellows:

Based on table 2, for men categorization, from 41 swimmers are included into 39 swimmers who have skill in swimming and 2 swimmers are not included to. For non-swimming categorization, from 19 swimmers, 3 of them are included into swimming while 16 of them are non-swimming. Hence, from 60 samples of athletes, $91 \%$ has explained the accuracy of classification $\{39$ (swimming skill) +16 (Non-swimming) $\} / 60$ swimmers samples $=55 / 60 \times 100 \%=91.7 \%$.

Based on table 3 , for women categorization, 37 swimmers are included into 37 swimming and none of them are included into non-swimming. Meanwhile, for non-swimming categorization, 3 of them are included into swimming and 20 of them are non-swimming. So, 60 of athletes' samples, $95 \%$ have explained the accuracy of classification: $\{37$ (swimming skill) +20 (Non-swimming) $\} / 60$ athletes' samples $=57 / 60 \times 100 \%=95 \%$.

Discussion. The instrument selection refers to the talent parameter test of Assistant Deputy of Sport Training, Ministry of Youth and Sports of the Republic of Indonesia 2015 which consisted of 12 instruments. These 12 instruments are consisted of 4 anthropometric instruments including; body height, body weight, arm span and foot length, and 8 physical measurement test instruments, including; sit and reach, max swimming sprint (25 m flying start), acceleration swimming (15 m push start), vertical jump, push up test (30 s), sit up test $(30 \mathrm{~s})$, pull up test and aerobic swim with vo2 max 15 mins. The anthropometric measurement is developed by adding the length of leg, the width of palm and the width of foot. This was done due to help the swimmer's speed in swimming. The length of leg and the width of foot are used to kick and the width of palm is used to paddle the water while swimming. The foot kick has positive effect toward swim velocity. It is also related to the reduction of body slope and resistive obstacle, while the arm action seems not having significant influence (Gourgoulis et al., 2014). Therefore, to interpret the influence of foot kick on propulsion forward, it is need to consider that booster is not merely depend on the driving force of arm and leg, but also on the resistive force within the body. 
The physical instrument test is divided into 2, namely bio motoric test and swimming ability test. In bio motoric test, the vertical jump test was changed into standing long jump test since in swimming the jump movement that goes forward is needed more than the vertical movement, especially in start position and glide movement. According to Papadopoulos et al, a huge distance can be reached as long as the jump is long. This was caused since (1) the horizontal transfer of mass center, (2) the reaction power has bigger result, (3) the reduction on launch angle from the mass center, and (4) the enhancement within the launch velocity from the mass center. Meanwhile in swimming ability test is added with floating test, gliding test and kick board for $15 \mathrm{~m}$. Stallman et al claimed that the basic water competition ability, such as floating, diving, swimming under water and swimming technique, is the important aspect of water competition concept (Stallman et al., 2011).

The result was supported by some previous studies that identified the anthropometric variable as the important predicator in swimming (Bond, et al., 2015; Zuniga et al., 2011; Lätt et al., 2010) and anthropometric characteristic that help coach to predict and follow the swimmer performance (Dokumaci, et al., 2017). The analysis of similar model which has been obtained can be used as an instrument to know the athlete's talent, such as defining whether woman swimmer aged around 7-10 has talent on swimming or other sport branches. For sport teacher, coach, parents and talent hunter can easily know whether the children have talent in swim or other sport branches by doing anthropometric measurement, bio motoric test and swim ability test, then the result is input to the discriminant similarity formula based on the children gender.

The making of computer software is needed to help sport teachers, coach, parents and talent hun- ter in having valid calculation on knowing children's talent. They can easily input the measurement result and test to the software and start the talent identification. The making of Delphi software called FASTI (FahrurRozi Swimming Talent Identification) is addressed to identify children aged 7-10 years old swimming talent using basic discriminant similarity formula.

Conclusion. The test instrument and measurement that used to identify men swimming athlete's talent are body weight, body height, arm span, leg length, palm width, foot length, sit and reach, pull up, sit up, $15 \mathrm{~m}$ kick board, $15 \mathrm{~m}$ swimming and 15 mins swimming. Meanwhile, the women swimming athlete's talent identifications are body height, arm span, leg length, palm width, foot length, sit and reach, pull up, sit up, standing long jump, $15 \mathrm{~m}$ kick board, $15 \mathrm{~m}$ and $25 \mathrm{~m}$ swimming and 15 mins swimming. The similarity model to identify swimming athlete's talent are; (1) men $=2.462+(0.124$ body weight $)+(0.082$ body height $)-(0.109$ arm span $)+(0,059$ leg length $)-$ $(0.744$ palm width $)+(0.124$ foot length $)-(0.026$ sit and reach $)+(0.005$ pull up $)+(0.039$ sit up $)-$ (0.037 $15 \mathrm{~m}$ kick board $)-(0.11715 \mathrm{~m}$ swimming $)+(0.00615$ mins swimming) and (2) women $=7.100+(0.133$ body height $)-(0.161 \mathrm{arm}$ span $)+(0.025$ leg length $)+(0.068$ palm width $)+(0.292$ foot length $)-(0.001$ sit and reach $)+(0.028$ pull up $)+(0.067$ sit up $)-(0.010$ standing broad jump $)-(0.10215 \mathrm{~m}$ kick board $)-$ (0.015 $15 \mathrm{~m}$ swimming $)+(0.00715$ mins swimming). The software that can be used to identify swimming athlete's talent is Delphi software that has been programmed named FASTI (FahrurRozi Swimming Talent Identification).

Suggestion. For further research, the writers suggest to add other factors that related to the swimming athlete's talent identification such as physiology, bio motoric and psychology.

\section{References}

1. Anshel MH, \& Lidor R. (2012). Talent Detection Programs in Sport: The Questionable Use of Psychological Measures. Journal of Sport Behavior.

2. Bompa T, \& Carrera M. (2015). Conditioning Young Athletes. In Modern Athlete \& Coach.

3. Bond D, Goodson L, Oxford S, Nevill A, \& Duncan M. (2015). The association between anthropometric variables, functional movement screen scores and $100 \mathrm{~m}$ freestyle swimming performance in youth swimmers. Sports, 3(1), 1-11.

4. Borms J. (1996). Early identification of athletic talent. Keynote Address to the International Pre-Olympic Scientific Congress.

5. Cooke C, Cobley S, Till K, \& Wattie N. (2010). Searching for sporting excellence: talent identification and development. British Journal of Sports Medicine. https://doi.org/10.1136/bjsm.2010.078725.220

6. Dokumaci B, Aygün C, Doğan DD, \& Atabek H Ç. (2017). Investigating the Anthropometric Variables and Bio-Motoric Properties in Male and Female Swimmers. International Journal of Sport Culture and Science, 5(4), 274-284.

7. Elferink-Gemser M, Visscher M, \& Lemmink K. (2005). Today's talented youth field hockey players, the stars of tomorrow? A study on talent development in field hockey. 
8. Faber I, Nijhuis-Van der Sanden M. W. G. \& Oosterveld F. G. J. (2012). A first step to an evidence-based talent identification program in the Netherlands; a research proposal. International Journal of Table Tennis Sciences 7, 15-18.

9. Gourgoulis V, Boli A, Aggeloussis N, Toubekis A, Antoniou P, Kasimatis P, ... Mavromatis G. (2014). The effect of leg kick on sprint front crawl swimming. Journal of Sports Sciences, 32(3), 278-289.

10. Kondrič M. (2009). The expert system for orientation of children into table tennis in the Republic of Slovenia. Scientific Approach in Table Tennis and Tennis in Slovenia.

11. Lätt E, Jürimäe J, Mäestu J, Purge P, Rämson R, Haljaste K, ... Jürimäe T. (2010). Physiological, biomechanical and anthropometrical predictors of sprint swimming performance in adolescent swimmers. Journal of Sports Science \& Medicine, 9(3), 398.

12. Maksum A. (2012). Metodologi penelitian dalam olahraga. Surabaya: Unesa University Press.

13. Parsonage JR, Williams RS, Rainer P, McKeown I, \& Williams MD. (2014). Assessment of conditioningspecific movement tasks and physical fitness measures in talent identified under 16-year-old rugby union players. Journal of Strength and Conditioning Research. https://doi.org/10.1519/JSC.0000000000000298

14. Régnier G, Salmela J, \& Russell SJ. (1993). Talent detection and development in sport. Handbook of Research on Sport Psychology, 290-313.

15. Russell K. (1989). Athletic talent: from detection to perfection. Science Periodical on Research and Technology in Sport, 9(1), 1-6.

16. Stallman RK, Kjendlie PL, Haugen K, Melby M, de Faveri T, \& Nesheim R. (2011). A Norwegian Model for Swimming Competency. Proceedings of the World Drowning Prevention Conference.

17. Van Den Bosch J, \& De Cocq C. (2006). Sportief talent ontdekken. Acco.

18. Vrljic K, \& Mallett CJ. (2008). Coaching knowledge in identifying football talent. International Journal of Coaching Science.

19. Williams AM, \& Reilly T. (2000). Talent identification and development in soccer. Journal of Sports Sciences. https://doi.org/10.1080/02640410050120041

20. Zuniga J, Housh TJ, Mielke M, Hendrix CR, Camic CL, Johnson GO, ... Schmidt RJ. (2011). Gender comparisons of anthropometric characteristics of young sprint swimmers. The Journal of Strength \& Conditioning Research, 25(1), 103-108.

Надійшла 28.10.2019

\section{Information about the authors}

Fahrur Rozi

Hari Setijono

Nining Widyah Kusnanik

f.rozifahrur@gmail.com

State University of Surabaya

Jl. Ketintang, Surabaya 60231 Indonesia 